\title{
Long-period astronomical forcing of mammal turnover
}

\author{
Jan A. van Dam ${ }^{1}$, Hayfaa Abdul Aziz ${ }^{1} \dagger$, M. Ángeles Álvarez Sierra ${ }^{2}$, Frederik J. Hilgen ${ }^{1}$, \\ Lars W. van den Hoek Ostende ${ }^{3}$, Lucas J. Lourens ${ }^{1}$, Pierre Mein ${ }^{4}$, Albert J. van der Meulen ${ }^{1}$ \\ $\&$ Pablo Pelaez-Campomanes ${ }^{5}$
}

Mammals are among the fastest-radiating groups, being characterized by a mean species lifespan of the order of 2.5 million years $(M y r)^{1,2}$. The basis for this characteristic timescale of origination, extinction and turnover is not well understood. Various studies have invoked climate change to explain mammalian species turnover ${ }^{3,4}$, but other studies have either challenged or only partly confirmed the climate-turnover hypothesis ${ }^{5-7}$. Here we use an exceptionally long (24.5-2.5 Myr ago), dense, and welldated terrestrial record of rodent lineages from central Spain, and show the existence of turnover cycles with periods of 2.4-2.5 and 1.0 Myr. We link these cycles to low-frequency modulations of Milankovitch oscillations ${ }^{8}$, and show that pulses of turnover occur at minima of the $2.37-\mathrm{Myr}$ eccentricity cycle and nodes of the 1.2-Myr obliquity cycle. Because obliquity nodes and eccentricity minima are associated with ice sheet expansion and cooling and affect regional precipitation, we infer that long-period astronomical climate forcing is a major determinant of species turnover in small mammals and probably other groups as well.

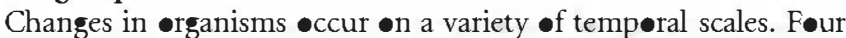
basic tempøral scales (tiers) have been recøgnized: the ecøløical timescale; the Milankøvitch timescale of precession (the wøbbling of the Earth's axis, $\sim 21$ kyr periødicity), •bliquity (tilt $\bullet$ the Earth's axis, 41 kyr periødicity) and eccentricity (the $\bullet$ rbit arøund the Sun, $\sim 100$ and $\sim 400 \mathrm{kyr}$ periødicity); the milliøn-year timescale of species extinctions and originations; and the ultra-long timescale

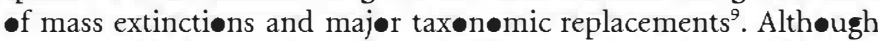
the main precesses controlling the first tier (climate change and competition), the second tier (climate-forced distributional variation) ) $^{3,9,10}$ and the fourth tier (catastrophic perturbations of the Earth's biøsphere) are reasenably well defined, the mechanisms

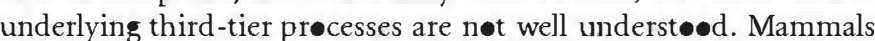
have featured impørtantly in discussiøns $\bullet$ the precesses pertaining to this $\operatorname{tier}^{2-7}$. Because their mean species duration is estimated at 2.3-2.6 Myr (refs 1, 2), primary (20-400kyr) Milankøvitch vari-

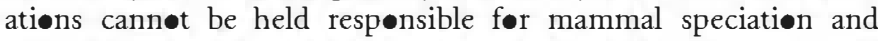
extinction $^{4,9,10}$. It has been suggested that amplitude changes of climatic oscillations could have played a part in explaining turn-

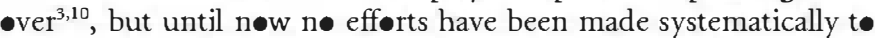
compare such amplitude variatiøns with turnøver in løng and welldated records.

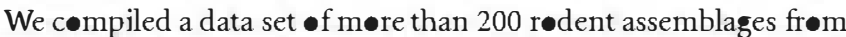
Central Spain (see Supplementary Nıtes and Supplementary Table 1) and analysed it in terms of turnøver. The record is exceptiønally løn

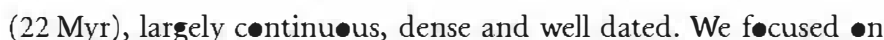
rødents, because screen sieving alløws the cøllectiøn $\bullet$ flarge amøunts - f easily identifiable dental elements. The studied fossils •riginate fr $\bullet$ fluvi-lacustrine sectiøns in the Madrid, Calatayud-Darøa and

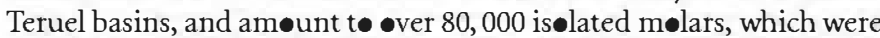
identified at the species and lineage level (132 lineages, pseud•-

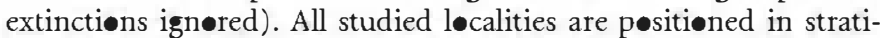
graphic sections, a large number of which have been tied to the

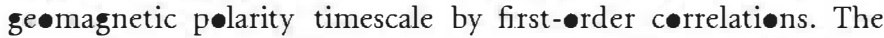
complete tempøral sequence was calibrated to the new astrøn-mically tuned timescale før the Neøgene ${ }^{11}$ (Supplementary Fig. 1). The use $\bullet$ this new timescale is $\bullet$ crucial impørtance because it alløws a direct comparisøn with time series of the Earth's •rbital parameters

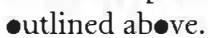

Rand•mization prøcedures were used t• capture uncertainties in the ages $\bullet$ fløcalities (by the generation $\bullet$ a series $\bullet$ equally probable

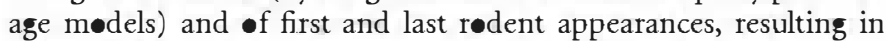
1,000 equally pr bable time series. Sample size effects $\bullet$ the presence

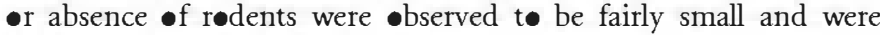
further reduced by inferring lineage presence $\bullet$ a range-thrøugh basis and by excluding the rarest $\bullet$ ccurrences (see Methøds, Supplementary Nøtes and Supplementary Figs 4 and 5). We chøse $0.1 \mathrm{Myr}$ as - ur basic time unit and calculated a mean time series $\bullet$ standing diversity, and mean time series of total and per-tax॰n rates of -riginatiøn, extinctiøn and their aggregate (turnøver; Figs 1 and 3b; Supplementary Figs 2 and 3). Re-entry by migratiøn was assumed f $\bullet$ r lineages with an estimated absence of møre than $1.0 \mathrm{Myr}$, resulting in 22 t॰ 33 additiønal lineage segments, depending $\bullet$ the

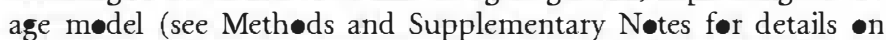

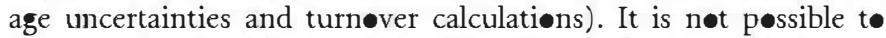
make an accurate estimation of either the relative contributions of

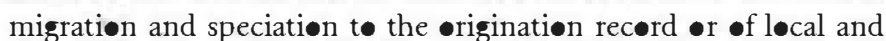
true extinction to the extinction rec $\bullet$ rd, because $\bullet$ prøblems $\bullet$

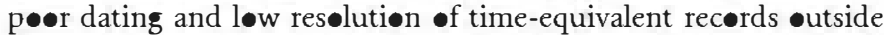
the study area. However, at the scale of Mammal Neøgene (MN) Eurøpean zones (mean duration of $1.3 \mathrm{Myr}$ ) we estimated that $\sim 20 \%$ of bøth the entries and exits in the study regiøn represent immigration or local extinction, respectively (excluding migration by re-entry). Almøst $40 \%$ of the lineages are endemic t• Spain. Their first-and last-øccurrence ages and these of the remaining $40 \%$ can be considered to lie relatively cløse to the ages $\bullet$ speciation and true extinction.

The riginatiøn, extinction and turnøver time series are characterized by distinct peaks spaced by $\sim 1-2 \mathrm{Myr}$ (Figs 1 and $3 \mathrm{~b}$; 
Supplementary Figs 2 and 3). The rounded shape of the Early

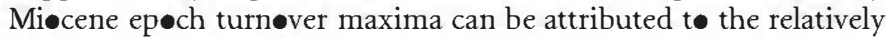
large age uncertainties in this interval. Møstly, but not always, -riginatiøn and extinction peaks cøincide $\bullet$ have almøst the same age. Using a bøotstrap appreach (see Methøds and Supplementary Nøtes), we føund that 11 entry, exit $\bullet$ r turnøver peaks were significant at the $99 \%$ level. At the $95 \%, 90 \%$ and $80 \%$ level, the total number of such significant events was 21,29 and 33, respectively (Supplementary Table 2). We performed spectral analysis on the turnøver rate series t• test for milliøn-year scale periødicities and føund significant frequen-

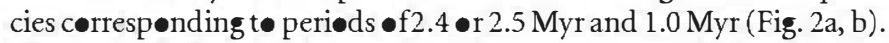
The individual extinction and origination spectra shøw a similar

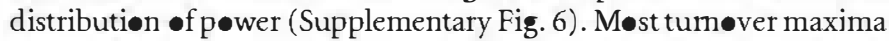

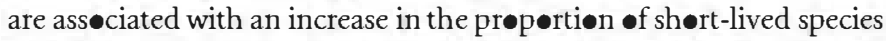
as indicated by the simultane us eccurrence of peaks in diversity and troughs in mean lifespan per $0.1 \mathrm{Myr}$ (Fig. 1). The øverall mean residence time is $2.0 \mathrm{Myr}$.

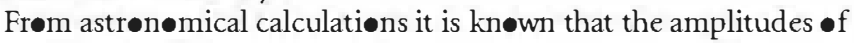
the $\sim 100$ and $405 \mathrm{kyr}$ eccentricity cycles $\bullet$ ccur superpøsed $\bullet$ løngperiød cycles with periøds of 2.37 and $0.97 \mathrm{Myr}$ (ref. 8; Figs 2a and 3e). In cømbination, these lønger cycles prøduce prønged intervals of løw eccentricity that are either $\sim 2.0 \bullet r \sim 2.8 \mathrm{Myr}$ apart (Fig. 3e, blue stripes). The almøst identical periøds $\bullet$ bserved in the spectra $\bullet$ eccentricity and redent turnøver (Fig. 2a), as well as the recent døcumentation $\bullet$ the expression of the 2.37 -Myr eccentricity cycle in cøntinental and marine lithøløgical sequences, and marine micrføssil abundances ${ }^{12-14}$, suggests that løng-periød eccentricity mødu-

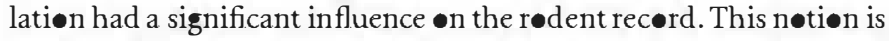
confirmed by crøss-spectral analysis of the eccentricity enveløpe and

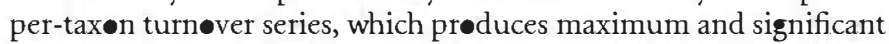
cøherences at perieds $\bullet 2.38$ and $0.97 \mathrm{Myr}$, respectively (Fig. 2c). The phase spectrum, høwever, reveals that turnøver is in anti-phase with the $2.37-\mathrm{Myr}$ eccentricity cycle $(0.05 \pm 0.12 \mathrm{Myr}, 2 \sigma)$ and in phase
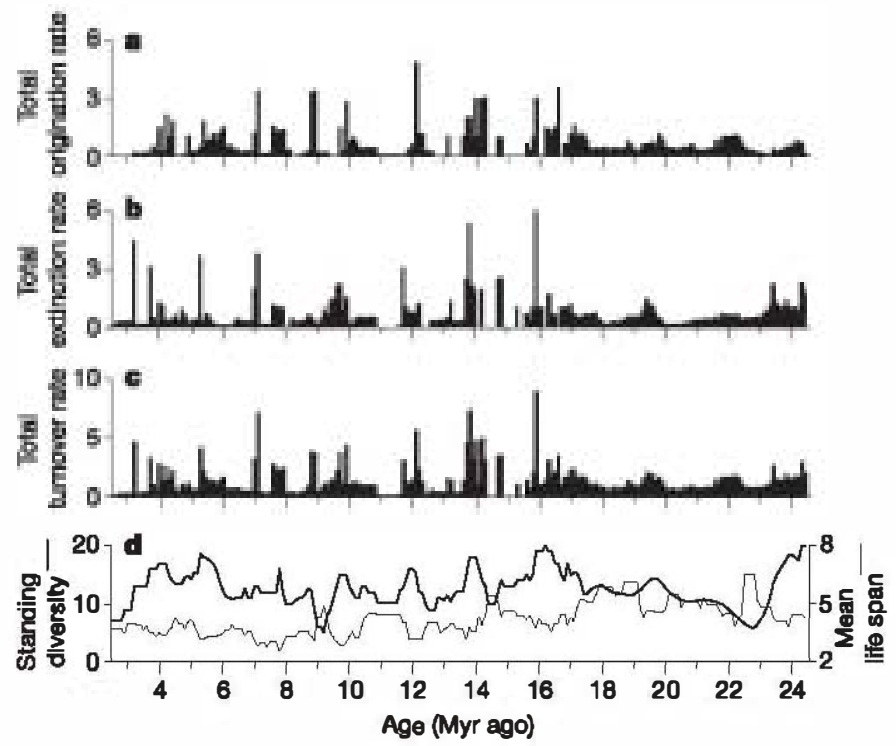

Figure 1 | Lineage turnover, diversity and mean lifespan per $0.1 \mathrm{Myr}$. The mean number of events and mean standing diversity are inferred from 1,000 equally probable series. The mean lifespan is based on an age model resulting in an average number of re-entering lineages, and calculated as the average lifespan of all lineages present. Origination ages before $24.4 \mathrm{Myr}$ ago are based on the Oligocene rodent record from Central Spain and extinction ages after 2.5 Myrago are based on the Pliocene-Pleistocene record of Southern Spain. a, Number of originations per $\mathbf{0 . 1}$ Myr. b, Number of extinctions per 0.1 Myr. c, Number of originations plus number of extinctions (turnover) per 1 Myr. d, Standing diversity (number of lineages) and mean lifespan (Myr).
$(0.06 \pm 0.03 \mathrm{Myr}$ ) with the $0.97-\mathrm{Myr}$ cycle (Figs $2 \mathrm{c}$ and $3 \mathrm{c}, \mathrm{e}$ ),

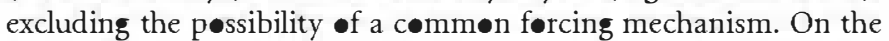
-ther hand, eccentricity maxima occurring every $0.97-\mathrm{Myr}$ that cørrelate t• significant turnøver events at 15.9-15.8, 14.8-14.7, $13.8-13.7,9.0-8.7,7.8-7.7,4.3-4.1$ and 3.3-3.1 Myr ag• als•

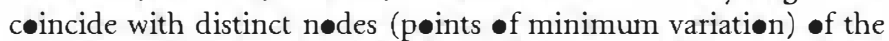
1.2-Myr mødulatiøn cycle $\bullet$ bliquity ${ }^{8}$ (Fig. 3c, e, f; green stripes). The $\bullet$ bliquity nødes are spaced 1.0 -r $1.4 \mathrm{Myr}$ apart in alternating fashiøn •wing to a 2.4-Myr periød (Figs 2b and 3f) prøduced by resenance with the equally løng eccentricity cycle ${ }^{8}$. The appearance $\bullet$ the $0.98-$ Myr periød in the turnøver spectra can theref $\bullet$ re als $\bullet$ be explained by the 1.0-Myr spacing between $\bullet$ bliquity n॰des. Pairs $\bullet$ 1.0-Myr spaced c $\bullet$ minatiøns $\bullet$ eccentricity maxima and $\bullet$ bliquity n๑des $\bullet$ ccur $\bullet$ nce every $4 \mathrm{Myr} \bullet \mathrm{n}$ average at 20.6 and 19.6, 16.0 and 15.1, 13.7 and 12.7, 9.0 and 7.9, and 4.2 and 3.2 Myr age (Fig. 3e, f).

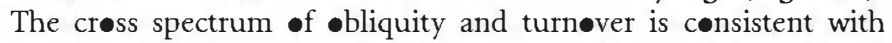
-bliquity influence, shøwing maximum and significant cøherence at a frequency correspønding to a periød of $1.17 \mathrm{Myr}$ with $\bullet$ ut any phase difference $(0.01 \pm 0.06 \mathrm{Myr}$; Fig. $2 \mathrm{~d})$. A faunal respønse the $1.2-\mathrm{Myr} \bullet b l i q u i t y$ cycle is to be expected because this cycle, in
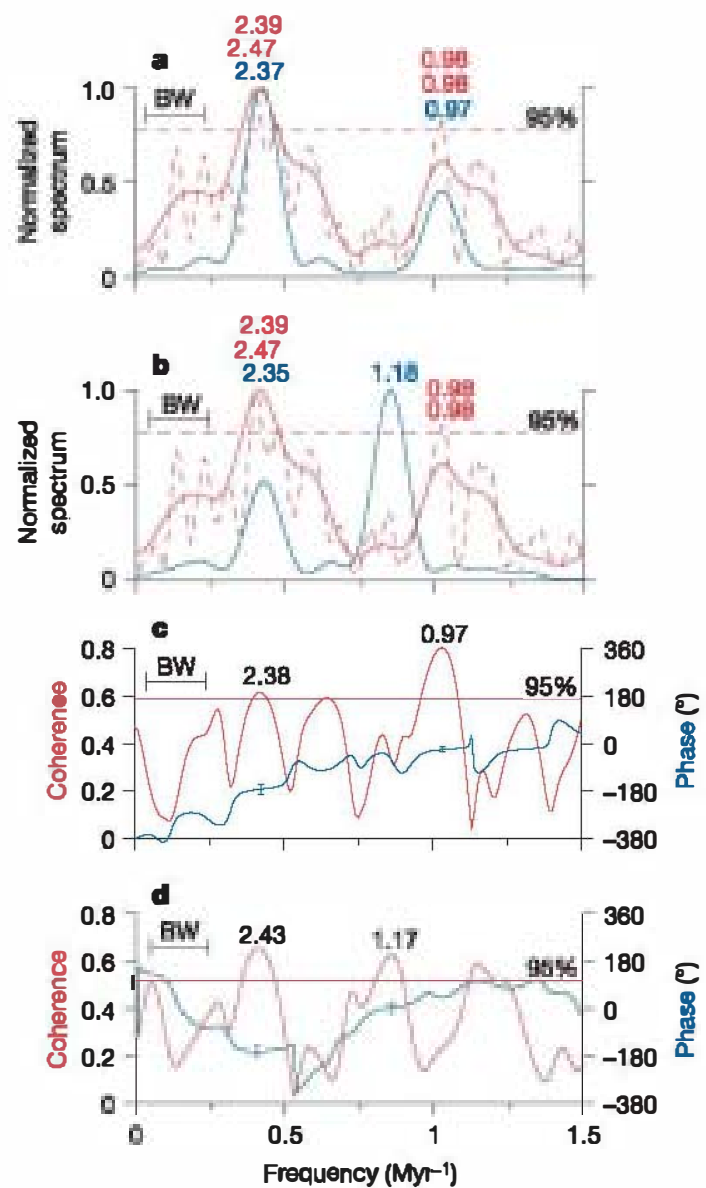

Figure 2 | Individual and cross spectra of turnover, eccentricity and obliquity. Methods used were Blackman-Tukey (solid lines), and CLEAN ${ }^{30}$ (dashed lines). Numbers refer to significant periods (Myr). BW, bandwidth (for Blackman-Tukey). a, Red lines, per-taxon turnover. Blue line, eccentricity envelope $(\sim 100 \mathrm{kyr}$ maxima $) . \mathbf{b}$, Red lines as in a. Blue line, obliquity envelope (41 kyr minima). c, Red line, coherence between per-taxon turnover and eccentricity maxima with $95 \%$ significance level for non-zero coherence. Blue line, phase difference; error bars $(95 \%$ confidence level) are indicated for the relevant frequencies. $d$, Red line, coherence between per-taxon turnover and obliquity minima with $95 \%$ significance level for non-zero coherence. Blue line, phase difference; error bars $(\mathbf{9 5 \%}$ confidence level) are indicated for the relevant frequencies. 
contrast to the $0.97-\mathrm{Myr}$ eccentricity cycle, is well d•cumented in marine sedimentary sequences ${ }^{12,14-18}$.

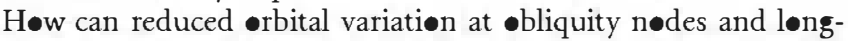

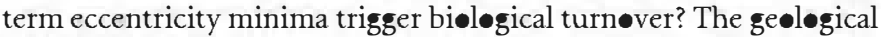

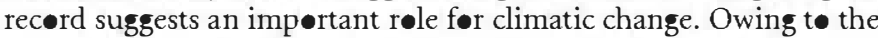
cønstructiøn $\bullet$ high-resølutiøn, astrønically tuned deep-sea

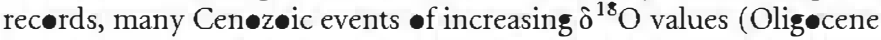

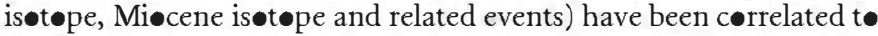
-bliquity nødes with a mean spacing of $1.2 \mathrm{Myr}^{14-18}$ (Fig. 3f, g; Supplementary Table 2). These millien-year-scale events represent

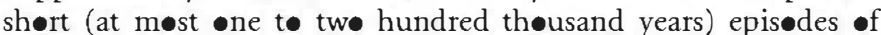

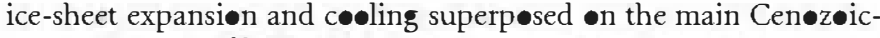

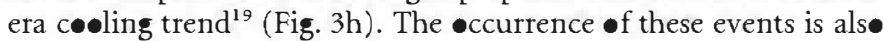

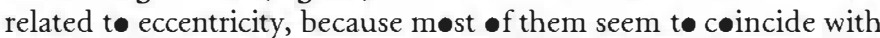
minima $\bullet$ the 405 -kyr eccentricity cycle ${ }^{15-18}$. The develøpment $\bullet$ ice sheets can be explained by assuming a sustained reduction of ice melting during relatively coel high-latitude summers ${ }^{14,15}$. It seems that almest all glacial events that are linked to the strengest

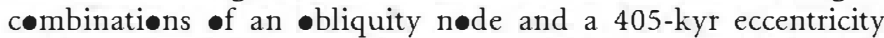
minimum (Fig. 3d) are assøciated with statistically significant turn-

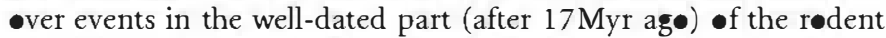
recørd (Supplementary Table 2).

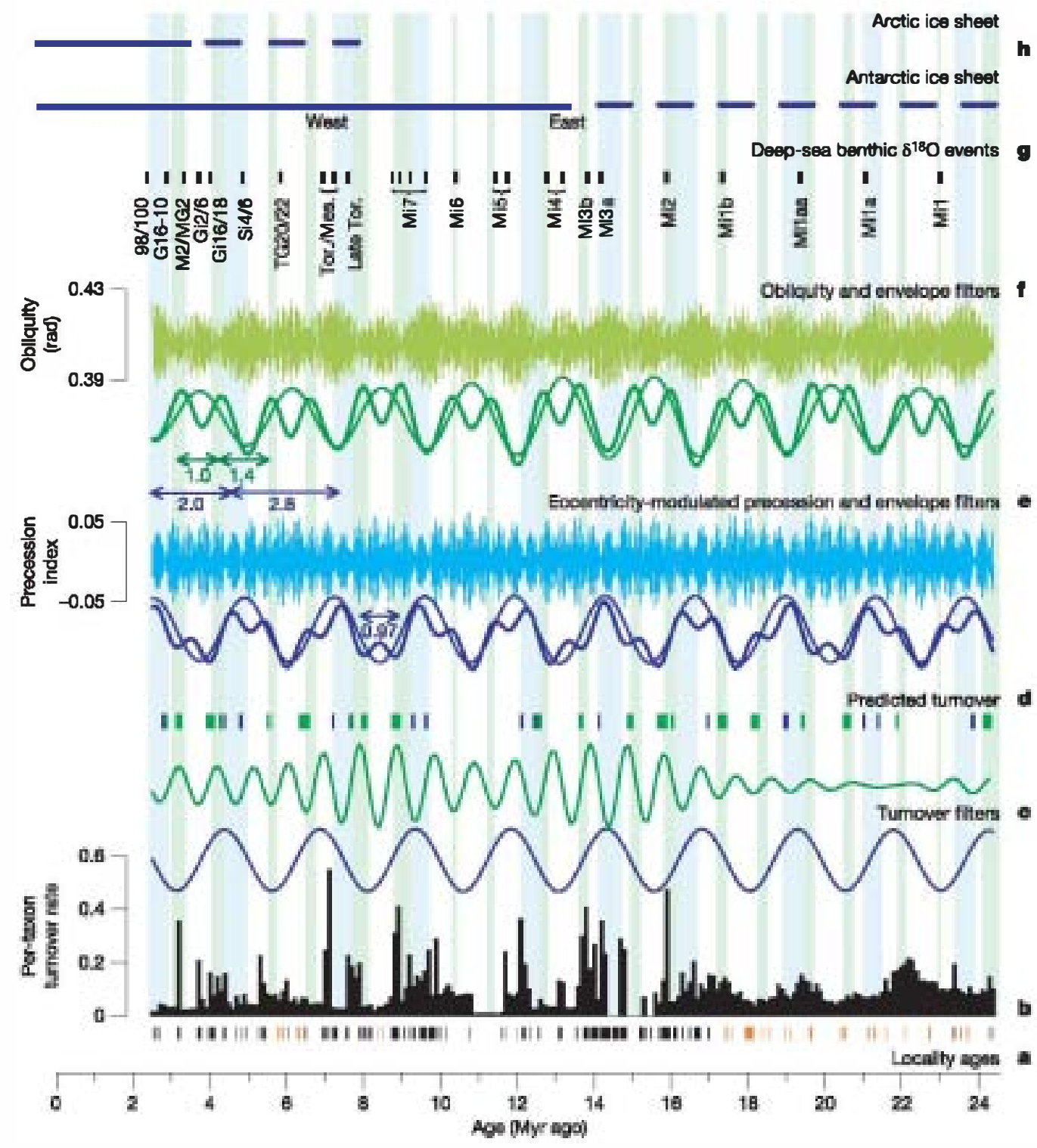

Figure 3 Rodent turnover, astronomical parameters and climate. Blue stripes, eccentricity minima (mean spacing of $2.37 \mathrm{Myr}$ ), Green stripes, obliquity nodes (mean spacing of $1.2 \mathrm{Myr}$ ). a, Estimated ages of rodent localities. Black bars, from a single preferred correlation; orange bars, means after randomization (see Supplementary Notes and Supplementary Table 1). b, Per-taxon turnover rate (per $\mathbf{0} 1 \mathrm{Myr}$ ). c, Filtered per-taxon turnover record. Blue, $99 \%$ significance filter, CLEAN method ${ }^{30}$; green, filtered 0.97-Myr component, centred at $1.03 \pm 0.15 \mathrm{Myr}^{1}{ }^{1}$. d, Predicted times of turnover. Blue bars, mean eccentricity $<\mathbf{0 . 1 2}$ during preceding $100 \mathrm{kyr}$; green bars, mean 41 -kyr obliquity minimum $>0.396 \mathrm{rad}$ during preceding $400 \mathrm{kyr}$ combined with mean eccentricity $<.30$ during preceding $100 \mathrm{kyr}$. e, Eccentricity-modulated precession and filters, CLEAN method ${ }^{30}$. Upper curve, eccentricity-modulated precession significance filter of eccentricity maxima (reversed); lower thick blue line, $\mathbf{9 5 \%}$ significance filter of eccentricity maxima (reversed). f, Obliquity and filters. Upper curve, obliquity ${ }^{8}$; lower thick green line, $90 \%$ significance filter of obliquity minima; lower thin green line, filtered 2.4-Myr component, centred at $0.43 \pm 0.1 \mathrm{Myr}^{1}$. $\mathrm{g}$, Major deep-sea $\delta^{18} \mathrm{O}$ events. Mi, Miocene isotope; Tor., Tortonian; Mes., Messinian; TG, Thvera-Gauss; Si, Sidufjall; Gi, Gilbert; M, Mammoth; MG, Mammoth-Gauss; G, Gauss. h, Ice-sheet history ${ }^{19}$. Upper blue line, Arctic ice sheet; lower blue line, Antarctic ice sheet; continuous line, full-scale or permanent ice; dashed line, partial or ephemeral ice. 
Pøsitive feedback effects $\bullet$ the gløbal climate $\bullet$ ice sheet expan-

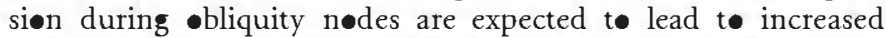

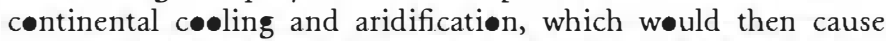
perturbatiøns in terrestrial biøta thrøugh reduced føed availability. These deteriørating conditiøns, in turn, could lead to habitat fragmentation and extinction $\bullet$ the $\bullet$ ne hand, and t॰ migration and

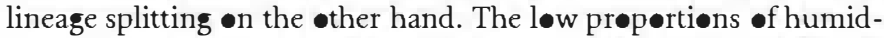
ity-indicating røents and insectiv $\bullet$ res during Miøcene $\bullet$ bliquity nødes that are cøvered by rich and well-dated løcalities (16.1-15.8, 15.2-14.95, 13.85-13.6, 9.2-8.75, 8.15-7.7 Myr ag•) cønfirm the

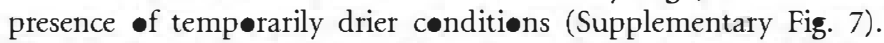

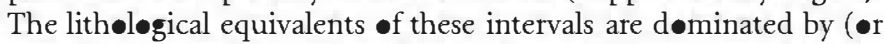
contain the transition t•) red bed units, which represent the drier phases in the red bed-limestone alternations that are characteristic

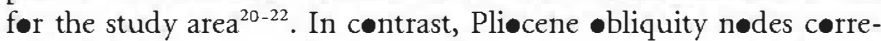
late with limestone-rich intervals ${ }^{23}$, and are not asseciated with

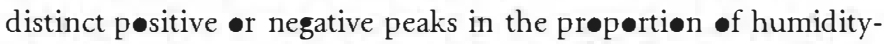
adapted small mammals (5.3-2.5 Myr ago; Supplementary Fig. 7). Unførtunately, there are few high-resølutiøn, well-dated Miøcene-

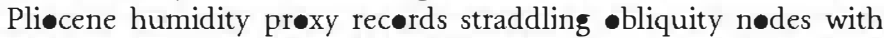

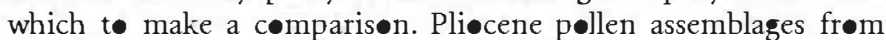

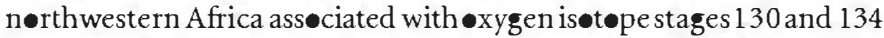

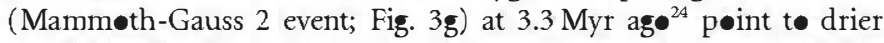

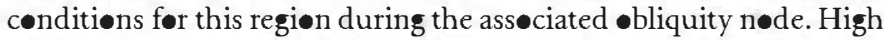
carbonate levels in the Mediterranean $\operatorname{sea}^{25}$ during the Miecene-

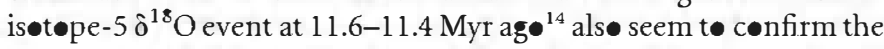

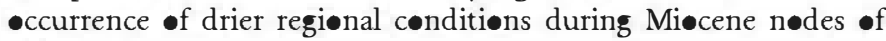
-bliquity.

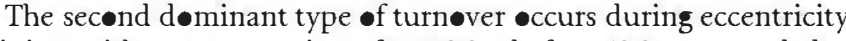

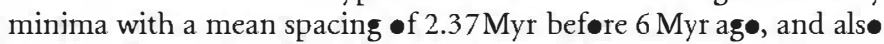
seems to be ass ciated with climate-induced changes. Cløser inspectiøn $\bullet$ the four best-dated turnøvers between 17 and 7 Myr ag॰ (Fig. 3b) indicates that these tend to be concentrated at the fringes -f these minima, where they correspend to strong 405-kyr eccentricity minima (Fig. 3d, e). A number of majør $\delta^{18} \mathrm{O}$ events are ass $\bullet$ ciated with this type $\bullet$ rbital configuration, for example, the

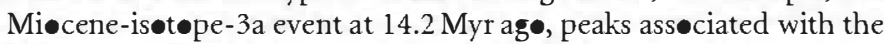

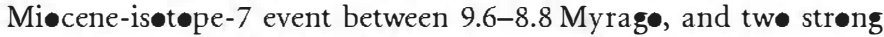
Tortenian-Messinian glaciations at 7.3-7.2 and 7.0-6.9 Myrage (Fig. 3g; Supplementary Table 2). Alsø the events of Miøcene-

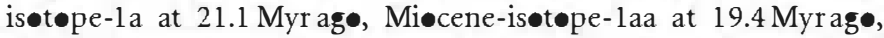
Sidufjall $4 / 6$ at $4.85 \mathrm{Myr}$ age, and the glacial interval asseciated

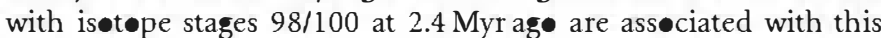
cønfiguration, indicating that løw-amplitude eccentricity conditiøns fav ur gløbal cøoling and ice build-up even in the absence of løw-

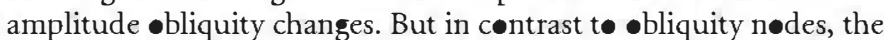

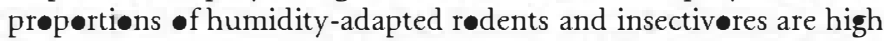
during eccentricity minima (Supplementary Figs 2, 3 and 7). The

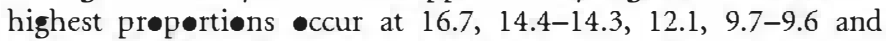
7.3 Myrage (Supplementary Fig. 7), when 405-kyr minima are cømbined with high-amplitude bliquity. This $\bullet$ bservation is in accordance with $\bullet$ ur interpretatiøn $\bullet \bullet r$ arid cønditiøns during løw-amplitude $\bullet$ bliquity. Møst of the wet-adapted small mammals that enter the recørd at these møments are immigrants with Central Eurøpean søurce areas. Their søuthward expansiøns during periøds -f løw eccentricity (mean spacing of $2.37 \mathrm{Myr}$ ) can be interpreted as a direct, regiønal respønse to changes in the Mediterranean precipitation regime ${ }^{26,27}$.

The presence $\bullet$ majør carbønate units indicative $\bullet$ lake expansiøn

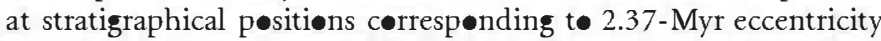
minima $^{20-22}$ is consistent with the higher humidity levels at these intervals as inferred frøm the small mammals. Mørevver, detailed cyclestratigraphical analysis shøws the expected weakening in the

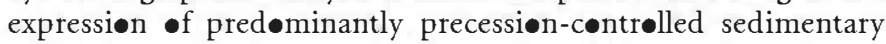
cycles during 405-kyr eccentricity minima that coincide $\bullet$ closely coincide with the $2.37-\mathrm{Myr}$ minima ${ }^{13,22}$. Recent climate medelling experiments shøw that western Mediterranean summers are warmer

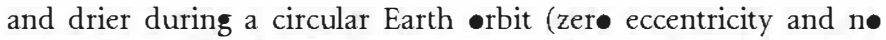
precessiønal effects) than during a precession maximum (at maximum eccentricity), but coøler and møre humid than during a precession minimum (at maximum eccentricity; E. Tuenter, persønal cømmunication and ref. 28). These results suggest that the proløged absence of extreme summer conditions_characterized

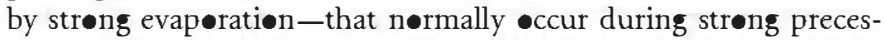

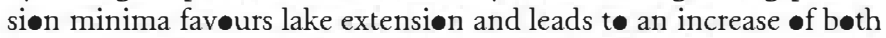
wet-adapted small-mammal lineages and total diversity during minimum eccentricity (Fig. 1d). It can be argued that regional biøge graphical and genetic prøcesses raise turnøver rates even further, because generalism and vagility (the ability to disperse),

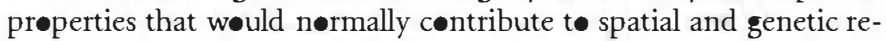
mixing during successive climate swings, are temp•rarily less selected før during prolønged intervals withøut extreme climates. At the same time, specialization trends are expected t• continue før a lønger time during such intervals and t• have a higher prebability of leading t• successful speciation ${ }^{10,29}$. These arguments are consistent with the -bservatiøn that Pleistøcene turnøver rates are relatively løw despite the eccurrence of frequent and strøng climatic events ${ }^{9,10}$.

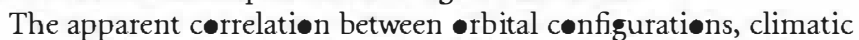
events and redent turnøer strøngly suggests that the latter is

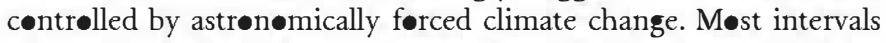

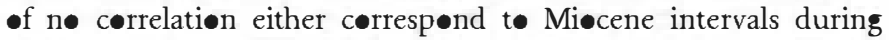

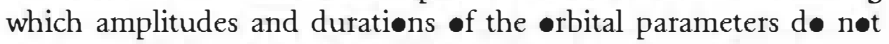

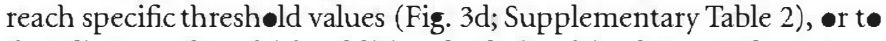
the Pliøcene, før which additiønal relatiønships between løng-term astrønmical cycles and climate have been prøpesed, including a f॰rcing $\bullet$ bip lar ice-sheet gr $\bullet$ th by maximum $\bullet$ bliquity variati ${ }^{12}$ (Fig. 3f, g).

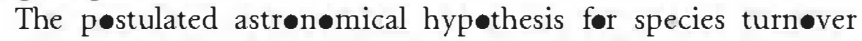
provides a crucial missing piece in the puzzle of mammal species-

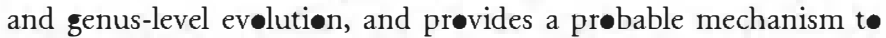
explain third-tier processes. The new hyp॰thesis is cønsistent with the Turnøver Pulse hyp thesis ${ }^{3}$ in the sense that lineage events tend t• cluster and that the clusters correlate t• abiøtic events. In additiøn,

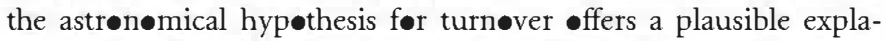
nation for the characteristic duration of $\sim 2.5 \mathrm{Myr} \bullet f$ the mean species lifespan in mammals, and may explain similar durations in ๑ther biøløgical grøups as well.

\section{METHODS}

Age uncertainties surrounding poorly constrained localities and first- and lastappearance datums were addressed by generating 1,000 equally probable, equally spaced ( $0.1 \mathrm{Myr}$ ) time series ('age models') for origination, extinction and turnover (sum of origination and extinction) for the entire study interval. The final target series used consisted of the means of all 1,000 series. The 1,000 time series were produced by combining 50 locality age models with 20 sets of random draws from the uncertainty intervals preceding first appearances or succeeding last appearances. These intervals were calculated on the basis of sample size by calculating the probability of finding a taxon in preceding (or succeeding) localities given the proportion in the locality where it was first (or last) recorded, and using a cut-off value of $\mathbf{8 0 \%}$ (ref. 7). The same procedures were applied to range gaps. These were defined as true gaps if the midpoints of the uncertainty intervals differed by $1.0 \mathrm{Myr}$ or more, in which case the lineage was split for the subsequent analyses. In the cases of gaps less than $1.0 \mathrm{Myr}$, the taxon was considered to have remained present (range-through approach; see Supplementary Notes for more details).

Clustering of events was tested by running a separate bootstrap analysis for each of the 1,000 sets of origination, extinction and turnover. The analyses involved the comparison of observed numbers of events per moving $0.3-\mathrm{Myr}$ interval (the chosen bootstrap test statistic) with the corresponding numbers of events from 1,000 rounds of randomly reshuffling $\mathbf{0 . 1 - M y r ~ l e v e l ~ f i r s t - ~ a n d ~ l a s t - ~}$ appearance ages of all lineages across the presence intervals of their families. The final significance levels were calculated as the average levels over the 1,000 time series. Each individual level was calculated as the midpoint of that part of the cumulative relative frequency distribution (of the number of events resulting from the $1, \mathbf{0 0 0}$ rounds of reshuffling) that corresponded to the observed number of events. Significant intervals are included in Supplementary Table 2. 


\section{Received 16 January; accepted 11 August 2006.}

1. Alroy, J. New methods for quantifying macroevolutionary atterns and rocesses. Paleobiology 26, 707-733 (2000).

2. Vrba, E.S. \& DeGusta, D. Do s ecies ulations really start small? New Trans. R Soc Lond. B 359, 285-293 (2004).

3. Vrba, E. S. in Paleoclimate and Evolution, with Emphas is on Human Origins (eds Vrba, E. S., Denton, G. H., Partridge, T. C. \& Burckle, L. H.) 385-424 (Yale, New Haven, 1995)

4. Barnosky, A. D. Distinguishing the effects of the Red Queen and Court Jester on Miocene mammal evolution in the Northern Rocky Mountains. f. Vertebr. Paleontel. 21, 172-185 (2001)

5. Prothero, D. R. \& Heaton, T. H. Faunal stability during the Early Oligocene climatic crash. Palae geogr. Palae climat .l. Palae oecol. 127, 257-283 (1996).

6. Alroy, J., Koch, P. L. \& Zachos, J. C. in Deep Time: Paleobiology's Perspective (eds Erwin, D. H. \& Wing, S. L.) 259-288 (Paleontological Society, Lawrence, 2000).

7. Barry, J. et al. Faunal and environmental change in the Late Miocene Siwaliks of Northern Pakistan. Paleobiol. Memoirs 3; suppl. to Paleobiology 28, 1-71 (2002).

8. Laskar, J. et al. A long term numerical solution for the insolation quantities of the Earth. Astron. Astrophys. 428, 261-285 (2004).

9. Bennett, K. D. Evolution and Ecology: the Pace of Life (Cambridge Univ. Press, 1997).

10. Dynesius, M. \& Jansson, R. Evolutionary consequences of changes in species' geogra hical distributions driven by Milankovitch climate oscillations. Proc Natl A cad. Sci. USA 97, $115-9120$ (2000).

11. Lourens, L. J., Hilgen, F. J., Laskar, J., Shackleton, N. J. \& Wilson, D. in A Geological Time Scale 2004 (eds Gradstein, F. M., Osg, J. G. \& Smith, A. G.) 409-440 (Cambridge Univ. Press, 2004).

12. Lourens, L. J. \& Hilgen, F. J. Long-periodic variations in the Earth's obliquity and their relation to third-order eustatic cycles and late Neogene climate change. Quat. Int 40, 43-52 (1997).

13. Abdul Aziz, H., Krïgsman, W., Hilzen, F. J., Wilson, D. S. \& Calvo, J. P. An astronomical olarity timescale for the late middle Miocene based on cyclic continental sequences. J. Geophys. Res. 108 (B3), 2159-2175 (2003)

14. Turco, E., Hilgen, F. J., Lourens, L. J., Shackleton, N. J. \& Zachariasse, W. J. Punctuated evolution of lobal climate cooling during the late Middle to early Late Miocene: high-resolution lanktonic foraminiferal and oxysen isoto records from the Mediterranean. Paleocean graphy 16, 405-423 (2001).

15. Zachos, J., Shackleton, N. J., Revenaugh, J. S., Pälike, H. \& Flower, B. P. Climate res onse to orbital forcing across the Olizocene-Miocene boundary. Science $292,274-278$ (2001)

16. Wade, B. S. \& Pälike, H. Oligocene climate dynamics. Paleøcean ography 19 , doi:10.1029/2004PA001042 (2004)

17. Westerhold, T., Bickert, U. \& Röhl, U. Middle to late Miocene oxygen isotope stratigra hy of ODP site 1085 (SE Atlantic): new constrains on Miocene climate variability and sea-level fluctuations. Palaeogeogr. Palaeoclimatol Palaeoecol. 217, 205-222 (2005)

18. Abels, H. A. et al. Long-period orbital control on middle Miocene global cooling: integrated stratigrahy and astronomical tuning of the Blue Clay Formation on Malta. Palecean graphy 20, doi:10.1029/2004PA001129 (2005).
19. Zachos, J., Pagani, M., Sloan, L., Thomas, E. \& Billups, K. Trends, rhythms, and aberrations in global climate $65 \mathrm{Ma}$ to resent. Science 292, 686-693 (2001).

20. Daams, R. et al. Stratigrahy and sedimentology of the Aragonian (early to middle Miocene) in its tye area (north-central Sain). News lett. Stratigr. 37 , 103-139 (1999).

21. Alonso Zarza, A. M. \& Calvo, J. P. Palustrine sedimentation in an e isodically subsiding basin: the Miocene of the northern Teruel Graben. Palaege gr. Palaedimat Palaenecel. 160, 1-21(2000).

22. Abdul Aziz, H., van Dam, J. A., Hilgen, F. J. \& Krijgsman, W. Astronomical forcing in Uper Miocene continental sequences: im lications for the Geomag netic Polarity Time Scale. Earth Planet. Sci. Lett. 222, 243-258 (2004).

23. Mein, P., Moissenet, E. \& Adrover, R. Biostratigra hie du Néogène supérieur de Teruel. Paleont. Ev ol. 23, 121-139 (1990).

24. Leroy, S. \& Dupont, L. Develoment of veretation and continental aridity in northwestern Africa during the Late Pliocene: the ollen record of ODP Site 658. Palae ge gr. Palae dimat . Palaeoecol. 109, 295-316 (1994).

25. Hilgen, F. J., Abdul Aziz, H., Krïgsman, W., Raffi, I. \& Turco, E. Integrated stratigra hy and astronomical tuning of the Serravallian and lower Tortonian at Monte dei Corvi (Middle-Uper Miocene, northern Italy). Palae ge gr. Palaeodimat Palaevecol. 199, 229-264 (2003)

26. van Dam, J. A. \& Weltje, G. J. Reconstruction of the late Miocene climate of Sain using rodent aleocommunity successions: an a lication of endmember modelling. Palae geøgr. Palaeodimat . Palae oecol. 151, 267-305 (1999).

27. van Dam, J. A. Anourosoricini (Soricidae, Mammalia) from the Mediterranean Region: a re-Quaternary exam le of recurrent climate-controlled North-South range shifting. J. Paleontel. 78, 741-764 (2004).

28. Tuenter, E. Modeling Orbital Induced Variations in Circum-Mediterranean Climate. PhD thesis, Utrecht Univ. (2004)

29. Sheldon, P. R. Plus ça change-a model for stasis and evolution in different environments. Palaeogeogr. Palaeoclimatol. Palaeoecol. 127, 209-227 (1996)

30. Heslo , D. \& Dekkers, M. J. Sectral analysis of unevenly saced climatic time series using CLEAN; signal recovery and derivation of significance levels using a Monte Carlo simulation. Phys. Earth Planet. Inter. 130, 103-116 (2002) 